\title{
One College's Use of an Open Psychology Textbook
}

John Hilton III

johnhiltoniii@byu.edu

Follow this and additional works at: https://scholarsarchive.byu.edu/facpub

Part of the Curriculum and Instruction Commons, Education Economics Commons, and the Higher Education Commons

\section{Original Publication Citation}

John Hilton III and Carol Laman. \&quotOne college's use of an open psychology textbook." Open Learning. 27(3), pp. 265-272. (2012).

\section{BYU ScholarsArchive Citation}

Hilton, John III, "One College's Use of an Open Psychology Textbook" (2013). Faculty Publications. 70. https://scholarsarchive.byu.edu/facpub/70 accepted for inclusion in Faculty Publications by an authorized administrator of BYU ScholarsArchive. For more information, please contact ellen_amatangelo@byu.edu. 
One College's Use of an Open Psychology Textbook

John Hilton III ${ }^{1}$

Brigham Young University

Carol Laman

Houston Community College

This is an Author's Original Manuscript of an article whose final and definitive form, the Version of Record, has been published in Open Learning published 14 September 2012 [copyright Taylor \& Francis], available online at:

http://www.tandfonline.com/doi/full/10.1080/02680513.2012.716657.

Key words: Open educational resources, open textbooks, electronic textbooks, Flat World Knowledge, open access, sustainability, Psychology

\footnotetext{
${ }^{1}$ Authors listed in alphabetical order. The two authors on this paper share co-authorship.
} 


\begin{abstract}
The high cost of textbooks is of concern not only to college students but also to society as a whole. Open textbooks promise the same educational benefits as traditional textbooks; however, their efficacy remains largely untested. We report on one community college's adoption of a free online psychology textbook. During the fall semester, 2011, 690 students used this book. Compared to students using a traditional text in the spring of 2011, students who used the free online textbook scored higher on departmental final exams, had higher GPAs in the class and higher retention rates.
\end{abstract}




\section{Introduction}

Rampell (2008) wrote, “The high prices of textbooks, which are approaching $\$ 1,000$ per year for an average student, have those students and their professors crying for mercy" (Rampell, 2008). In the United States, students spend 5.5 billion dollars each year on required textbooksand this only includes purchases made at on-campus bookstores - clearly underestimating the overall total given the frequency to which college students turn to the Internet for book purchases. (National Association of College Stores, 2009). The Government Accountability Office (GAO) (2005) reports that "Textbook prices nearly tripled from December 1986 to December 2004" (p. ii). While the foregoing statistics apply only to the United States, the difficulty is worldwide, as evidenced by India’s National Knowledge Commission, (2007).

Publishers have been criticized for producing books that are unnecessarily long, for publishing too-frequent revisions, and for bundling expensive and often unused resources with the books, making resale and the purchase of used books more difficult. (U.S. Government Accountability Organization, 2005). While professors are sometimes criticized for assigning expensive textbooks, Ayres (2005) states they are often unaware of the prices of these texts.

This problem of textbook costs is part of a larger issue, with Martin and Lehren (2012) reporting that in the United States alone, student loans (part of which funds are used for purchasing textbooks) are over one trillion dollars. While textbooks are only a portion of this total debt, for many students, particularly community college students, textbook prices can be a significant part of their overall college expenses (Buczynski, 2007).

One alternative to expensive textbooks is open textbooks which are traditionally available without charge online. These textbooks are part of a larger subset of Open Educational Resources (OER), educational resources that are freely available and licensed in such a way as to 
promote reuse and remix (Bissell, 2009, D'Antoni, 2009, Downes, 2007). Many efforts are underway to create and promote such open textbooks. These efforts include those made by local and national governments. For example, Caswell (2012) "describes an initiative of the Washington State community and technical colleges" that "is a large-scale curriculum redesign effort leveraging a variety of existing open educational resources as well as original content by our faculty course designers" (259). The intended result is that professors will be able to use OER to dramatically lower the cost that students pay.

Efforts are not limited to governments. Hilton and Wiley (2010) discuss several businesses that are publishing free digital textbooks. Of particular interest in the present study are textbooks published by Flat World Knowledge, a company which makes open textbooks available for free on the Internet and also sells inexpensive print versions and other auxiliary materials (Hilton and Wiley, 2011). Flat World Knowledge (FWK) provides professors and students with the option of using free digital textbooks.

However while FWK and other organizations are making free digital textbooks available, many questions remain about student perceptions of such books, as well as the overall efficacy of open textbooks. Some question whether books that are distributed for free online will have the educational impact of full-color textbooks that have been vetted by traditional publishers. Brent, Gibbs, and Gruszczynska (2012) reported on several of the difficulties associated with finding and appropriately using OER. These issues can make it difficult for teachers or schools to adopt open textbooks. Because of the relatively low adoption rate of open textbooks, only a small amount of research has investigated its educational impact. Wiley et. al (in press) reported that a high school district that adopted open textbooks saw no change in their state standardized test 
scores. Because open textbooks are just now beginning to be adopted on a large scale, there have not yet been any replications of this study.

In this article we attempt to close this knowledge gap by reporting on Houston Community College's adoption of an open textbook for a core curriculum course, Introduction to Psychology. We first provide the context for this study, and then the results reported by the college.

\section{Context of the Study}

This study took place at Houston Community College (HCC), a large community college with more than 70,000 students. The 2011 HCC Fact Book shows a diverse institution; 33\% of its students are Hispanic, 33\% are African American, 17\% are white, 14\% Asian, and 3\% are classified as "other." (Houston Community College, 2012). Fifty-nine percent of the students are female, and forty-one percent are male.

Many students attending HCC have difficulty with the cost of college. Some students do not purchase books at all; other students use outdated editions or non-assigned books. In addition, the cost of textbooks may prevent students from taking an optimal course load. A reduced course load means more years in college and reduces the likelihood of completion. For these reasons, faculty were concerned that the cost of textbooks was interfering with student success. A faculty committee, with the support of administration, decided to make cost a primary consideration in the textbook adoption process.

In 2011, the discipline chair of psychology at HCC met with a representative from Flat World Knowledge (FWK) to discuss the possibility of adopting a free, online Flat World open text. As a result of this meeting and subsequent discussions, the psychology discipline committee decided to review the Flat World Introduction to Psychology textbook and consider 
customization and adoption. A needs assessment survey was completed by 264 students on four HCC campuses. Results of the survey indicated that $92 \%$ of students said they would use a free book and $43 \%$ said they would also buy a paper copy. Seven full-time instructors indicated their willingness to use the Flat World book in a pilot study.

Two traditional textbooks were also approved for use in the Introduction to Psychology course. Those are at the less-expensive end of the market (see Appendix 1 for information on these textbooks, as well as their cost). Multiple textbooks were adopted so that the different course instructors could select the textbook that would work best in their classroom. (In total, approximately sixty five full and part-time instructors teach psychology each semester).

One of the reported benefits of FWK textbooks is that as open textbooks they can be modified to better fit the need of local students. A group of six full-time and six adjunct HCC psychology faculty members participated in the adaptation of FWK's Introduction to Psychology textbook (written by Charles Stangor). The adaptation was necessary in order to lower the reading level to one that the faculty felt was appropriate for HCC students (twelfth grade) and to incorporate additional learning objectives and key terms that they had identified as being essential to the course. Additional video links, relevant examples, and cross-cultural information were also added to the text.

The editing was completed in June of 2011, and the HCC version of the FWK text was adopted for use in the fall of 2011. Over the summer and early fall, supplemental materials to match the text adaptation were developed for students to use and posted on an internal learning website. These materials included a supplementary handbook with objectives, teaching power points (which included questions, exercises, and video links), flash cards, online learning 
activities, a list of supplemental videos, a power point final exam review, and a narrated final exam review with slides (these resources are all available here).

In order to standardize the assessment of students across the different sections of Introductory Psychology, the department final exam was also adapted for this text. The committee used the department's existing final exam test bank to select 100 questions that were compatible with the FWK textbook. These questions covered the entire list of objectives and represented an approved number of easy, moderate, and difficult items as well as an approved balance of definition, concept, and application questions. The final exam was proofread by one adjunct and two full-time faculty members.

\section{Method}

With the above-mentioned materials prepared, seven HCC psychology faculty members did a pilot test of the FWK textbook in the fall of 2011. Because of the potential for problems with an online text and a new publisher, participation in the pilot was limited to full-time instructors. Those instructors taught on five different campuses, as well as in distance education sections. In total, twenty three sections (690 students) used the FWK textbook. HCC faculty members wanted to know whether students in these sections had any different educational outcomes that were related to the use of the new open textbook.

The department used three outcome measures to determine the efficacy of the FWK textbook. First, they took baseline data from a sample of classes that had been offered in the spring 2011 semester. Data included average class GPA, student withdrawal rate, and departmental final exam scores. This baseline information was compared with data from students who used the open textbooks the next semester (fall 2011). Second, two instructors used a traditional textbook in spring 2011 and the Flat World text in fall 2011. Each taught several 
sections in the spring and in the fall. The committee also examined the differences in the outcomes of these two sets of students. Third, the committee surveyed students regarding the open textbook.

\section{Results}

As shown in Table 1, students who used the open textbooks in the Fall of 2011 had better overall outcomes than those who used traditional textbooks in the Spring of 2011.

Table 1

Aggregated Data Spring 2011 (Traditional Text) v. Fall 2011 Free Text-Multiple Campuses and Instructors.

\begin{tabular}{|l|l|l|}
\hline & $\begin{array}{l}\text { Spring 2011 } \\
\text { (Traditional Textbook) }\end{array}$ & Fall 2011 (Open textbook) \\
\hline GPA & 1.6 & 2.0 \\
\hline Withdrawal rate & $14 \%$ & $7.1 \%$ \\
\hline Dept. Final Exam & $67.6 \%$ & $71.1 \%$ \\
\hline
\end{tabular}

Based on overall GPA's and the scores on the departmental final, it appears that the students who used the FWK did not suffer an educational setback. The grade point average and final test exam scores of students using the free book improved. Retention rates were also improved in classes that used the open textbooks.

The second set of comparisons was made by collecting data from two instructors each of whom taught between five and eight sections both in the spring of 2011 and the fall of 2011. These sections provide complete comparative data sets for GPA, final exam scores, and withdrawal rates. Table 2 provides a comparison of the outcomes in each semester for the first, "Instructor A," of the two instructors. 
Table 2

A comparison of Instructor A's student outcomes

\begin{tabular}{|l|c|l|}
\hline & $\begin{array}{c}\text { Sp. 2011 (Traditional Textbook) } \\
\text { 5 Sections (N-158) }\end{array}$ & $\begin{array}{l}\text { Fall 2011 (Open Textbook) } \\
\text { 6 Sections (N=182) }\end{array}$ \\
\hline GPA & 1.64 & 2.0 \\
\hline Withdrawals & $21 \%$ & $16 \%$ \\
\hline Dept. Final Exam & 65.4 & 73.2 \\
\hline
\end{tabular}

Instructor A recorded relatively large (over ten percent) increases in both GPA and final exam scores when using the open textbook. The withdrawal rate also was lowered by approximately $25 \%$.

Table 3 provides a comparison of the outcomes in each semester for the second instructor, "Instructor B."

Table 3

A comparison of Instructor B's student outcomes

\begin{tabular}{|l|c|l|}
\hline & $\begin{array}{l}\text { Spring 2011 (Traditional Textbook) } \\
7 \text { sections (N= approx. 210). }\end{array}$ & $\begin{array}{l}\text { Fall 2011 (Open Textbook) } \\
8 \text { sections (N=approx.240). }\end{array}$ \\
\hline GPA & 1.37 & 1.78 \\
\hline Withdrawals & $9.7 \%$ & $0.75 \%$ \\
\hline Dept. Final Exam & 65.86 & 66.25 \\
\hline
\end{tabular}

Like Instructor A, Instructor B recorded an increase in both GPA and exam final scores, but the change in the final exam score was negligible. The change in withdrawal rate was, however, quite dramatic in the sections that used the open textbook.

In addition to the measures of GPA, retention, and final exam scores, students were surveyed regarding their experience using the open textbook. At the end of the fall 2011 semester, students in 8 FWK sections were given a survey to obtain their feedback on the open textbook. 
Of the 157 students who responded to the survey question regarding the type of book they used, 57 (36\%) said they purchased a print copy. Only two (1\%) purchased an e-book, and $62 \%$ used the free version online. These usages correspond to previous research on FWK textbooks (Hilton and Wiley, 2010, 2011). In comparison, a survey given to students using the traditional textbooks at the end of spring 2011 showed that 198 (75\%) of students used a hard copy of the book, five (2\%) used an e-book, and fifty-eight (22\%) had rented a hard copy of their textbook from the HCC bookstore.

Eighty-four percent of students surveyed agreed with the statement that "Having a Free Online Book Helps Me Go to College.” Of the 108 students who responded to a question regarding the difficulty of using an online text $45(42 \%)$ said that it was easy, $28(26 \%)$ said that it was moderately easy, $26(24 \%)$ said that it was neither hard nor easy, $9(8 \%)$ said that it was moderately difficult. Zero students reported that it was difficult to use an online text.

\section{Discussion and Limitations}

The data collected in this study are relatively straightforward. Students who used open textbooks in the fall 2011 had better outcomes than those who used traditional textbooks in the spring of 2011. The difficulty is determining whether there is any causality between these two events or if another explanation might better account for the change in GPA, final exam scores and retention rates.

Alternate explanations for the improved outcomes noted in the open book group could be the Hawthorne effect or a volunteer bias on the part of those instructors who agreed to pilot these texts. It is also possible that the FWK textbook was simply a better textbook than those that were used in the spring of 2011 and that its free online nature had nothing to do with the change in student outcomes. 
Another uncontrollable outside influence was that a psychology discipline committee (separate from the textbook adoption committee) changed the objectives and final exam test bank for the fall of 2011. Thus there may have been a difference in difficulty level. In other words, either easier or more difficult material may have been covered by the fall 2011 exam. While the committee that made the changes did not evaluate the material as significantly different in difficulty level, it nevertheless remains a possibility.

Even if these factors are all held constant, and even if we assume that it was the new textbook that caused the improved scores, additional questions emerge. Did improved access to a textbook (because it was available for free online) result in the better results? Did the improvement in course outcomes result from the fact that the department was able to modify the textbook to more closely align it with their standards and course objectives?

It is similarly difficult to discern the degree to which the open textbook contributed to the decrease in withdrawal rates. Because student withdrawals during the first few weeks have multiple causes unrelated to textbooks, data was not collected for that time period (in the spring or the fall). The retention rates that were compared, therefore, were from final grade sheets.

Notwithstanding the lack of data indicating causality, there are several reasons to believe that the availability of a free online textbook contributes to better student outcomes. First, all students have access to a book, regardless of their ability to pay. Second, all students have access to that book before the first day and throughout the semester. Thus students can prepare in advance of class, and students who lost their book during the semester can still study online. Students can access the book from the library, their laptops, or even an Internet enabled phone. They can study anywhere they have Internet access, even if they have left their textbooks at home. Third, because faculty members are able to make adaptations to the text, they are able to 
include all of the department-identified key terms and objectives within the text. (Traditionally, the HCC Psychology Textbook Adoption Committee had only selected books that included 95\% of the objectives, or they had added supplements to provide information on the missing objectives.) Fourth, there are inherent advantages to digital texts. Students are able to directly link to videos and learning activities while reading the text and can use the "find" function to immediately locate key terms. Finally, faculty can be selective about which supplemental materials to use and can post them on internal websites or Learning Management Systems (LMS). Traditionally, in order to use supplemental materials students must go to publisher's websites. Those websites often have an overwhelmingly large selection of videos, activities, simulations, and quizzes. Furthermore, publisher sites often require students to learn an additional LMS or purchase access. Having an open textbook that allowed HCC to tailor supplemental materials and host them from their own website may have made it easier for students to access these materials.

\section{Directions for Future Study}

It appears that using an open textbook improved student learning as measured by final exam scores and GPAs. It also may have led to decreased levels of student withdrawal from class. Further research is needed to establish that open textbooks were the cause of these improved outcomes. This research should be replicated at a variety of campuses around the world. In addition to courses in psychology, the use of open textbooks in other subjects would be examined. Ideally research could include instructors willing to teach comparable sections using different texts.

This preliminary study shows that open textbooks can allow students to use their money for other textbooks, tuition, or living expenses. Free online textbooks can reduce the need for 
students to seek financial aid or work extra hours; and if they can save students money and at the same time lead to improved student outcomes, their role in the future of education will be significant. 


\section{Appendix One}

Textbooks Chosen by the HCC Psychology Department

In addition to the FWK textbook, the HCC Psychology department also selected two traditional textbooks for its introductory classes to be taught in the fall of 2011. The books, along with their costs to students are as follows:

Cengage: Weiten, Brief, $8^{\text {th }}$ edition. The price of a new loose-leaf copy at the HCC bookstore was $\$ 81.60$ and a used copy was priced at $\$ 61.20$.

Worth: Schacter, $1^{\text {st }}$ ed. The price of a new loose-leaf copy at the HCC bookstore was $\$ 64.30$ and a used copy was priced at $\$ 48.25$.

Both of the books featured free online learning materials and complete sets of instructor support materials. They also had options to purchase less expensive e-books. The Cengage book also offered a more expensive website with additional online learning activities and resources.

In contrast, the FWK was available for free online. A new print version was available at the HCC bookstore for $\$ 42.00$ or for $\$ 31.50$ (used). Digital supplements produced by HCC faculty were made available for free to HCC students. A modified FWK test bank and instructor supplements were also produced by the HCC faculty. FWK sells digital supplements to students and provides them for free to faculty members, but these Flat World supplements were not used since they did not match the customized version of the text.

By way of comparison, the five traditional textbooks from spring of 2011 had an average new cost of $\$ 110.88$. Most of these books required students to purchase digital supplements in addition to that price unless they purchased the e-book. One of those books was customized, but 
that may have added to the long term cost. Resale and purchase of customized books is generally limited to specific campus bookstores.

Notice of full disclosure: One of the authors of this study was involved in the adoption and modification of the textbook in question. The other author later used this textbook (outside of this study) while teaching a class. 


\section{References}

Ayres, I. (2005, Sept. 16). Just what the professor ordered. New York Times, pp. A2, 27. http://www.nytimes.com/2005/09/16/opinion/16ayres.html.

Bissell, A. (2009). Permission granted: Open licensing for educational resources. Open Learning, The Journal of Open and Distance Learning, 24, 97-106.

Brent, I., Gibbs, G., \& Gruszczynska, A. Defining openness: updating the concept of "open" for a connected world. Journal of Interactive Media in Education. http://jime.open.ac.uk/2012/05

Buczynski,J. (2007). Faculty Begin to Replace Textbooks with "Freely" Accessible Online Resources. Internet Reference Services Quarterly, 11:4, 169-179. http://dx.doi.org/10.1300/J136v11n04_11

Caswell, T. (2012). The Open Course Library of the Washington State Colleges. In Game Changers: Education and Information Technologies, ed. Diana G. Oblinger. Educause (Washington D.C.), pp. 259-262. http://www.educause.edu/Resources/GameChangersEducationandInform/CaseStudy2The OpenCourseLibrary/250347.

D’Antoni, S. (2009). Open Educational Resources: Reviewing initiatives and issues. Open Learning, The Journal of Open and Distance Learning, 24, 3-10.

Downes, S. (2007). Models for sustainable open educational resources. Interdisciplinary Journal of Knowledge and Learning Objects, 3, 29-44.

Hilton, J. \& Wiley, D. (2010). A sustainable future for open textbooks? The Flat World Knowledge story. First Monday, 15(8). http://www.uic.edu/htbin/cgiwrap/bin/ojs/index.php/fm/article/view/2800/2578

Hilton, J. \& Wiley, D. (2011). Open-Access Textbooks and Financial Sustainability: A Case Study on Flat World Knowledge. The International Review of Research on Open and Distance Learning, 12 (5). http://www.irrodl.org/index.php/irrodl/article/view/960/1860

Houston Community College (2012). 011-2012 Fact Book. http://www.hccs.edu/hcc/images/home\%20page\%20images/0-HCC\%2020112012\%20Fact\%20Book.pdf.

Martin, A. \& Lehren, A. W. (2012). A Generation Hobbled by the Soaring Cost of College. The New York Times. http://www.nytimes.com/2012/05/13/business/student-loans-weighingdown-a-generation-with-heavy-debt.html? $\mathrm{r}=3 \& \mathrm{ref}=$ business. 
National Association of College Stores. (2009). "Higher Education Retail Market Facts \& Figures 2009.” http://www.nacs.org/public/research/higher_ed_retail.asp.

National Knowledge Commission. (2007). Report to the nation 2007. New Delhi, Government of India. http://www.knowledgecommission.gov.in/downloads/report2007/eng/Report07.pdf

Overland, M. (2011, January 9). State of Washington to Offer Online Materials as Texts. The Chronicle of Higher Education. http://chronicle.com/article/State-of-Washington-toOffer/125887/.

Rampell, C. (2008, May 2). Free Textbooks: An Online Company Tries a Controversial Publishing Model. The Chronicle of Higher Education. http://chronicle.com/article/FreeTextbooks-An-Online/17947.

U.S. Government Accountability Organization (2005, July). College textbooks: Enhanced offerings appear to drive recent price increases (Publication No. GAO-05-806). http://www.gao.gov/new.items/d05806.pdf.

Wiley, D., Hilton, J., Ellington, S. Hall, T (in press). A Preliminary Examination of the Cost Savings and Learning Impacts of Using Open Textbooks in High School Science Classes. International Review of Research on Open and Distance Learning. 